\title{
STUDY OF EFFECTIVENESS OF TWO WEED MANAGEMENT METHODS ON THE ESTABLISHMENT OF INDIGENOUS TIMBER SPECIES IN THE GRASS INFESTED WET ZONE LANDS
}

\author{
D Tilakaratna \\ Research Officer, Forest Research Centre, \\ Kumbalpola.
}

The effectiveness of two manual weed control methods were studied for the establishment of tour timber species in a grass infested wet zone land. One method was the standard wedding practice used for plantation estahlishment by Forest Department. (Low stashing and strip weeding 3 limes during the $1^{\text {"l }}$ year. 2 times during the $2^{\text {nd }}$ year and one low slashing and patch weding during the third year). The other is high intensity (luxury) werding involving complete cultivation of the topsoil. Fourteen months observations and survival and height measurements were recorded.

Results indicate that three species. Artocerpus nobilis, Artocarpus heterophyllus and Filicium deripiens failed to sucecssfully estahlish and grow under hoth weeding methods. Other species. Dipterocarpus zeylanicus although established showed poor growth and vigour. The slight inprovement of survival and growth under luxury weeding does not justily the cost involved. 